\title{
LATIN AMERICAN TAXES AFFECTING INTER-AMERICAN TRADE
}

\author{
EDWIN D. FORD, JR.*
}

This article is intended as a practical guide for the North American manufacturer or merchant who contemplates embarking for the first time on business ventures in the Latin American republics to the south. ${ }^{1}$ It is not a digest of tax laws or procedure, nor can it serve as an index or bibliography on Latin American tax laws. Such a work would require volumes and many months to prepare. After it was finished, it would be of doubtful practical value, since the tax laws of the various Latin American countries are constantly changing, not only in their text but in their interpretation and application; by the time such a work was finished, it would be out of date.

In considering any matters affecting Latin America it must be remembered that it is divided into twenty entirely independent republics (not to mention the various colonies and dependencies controlled by European powers), each with its own political and historic heritage and with its current policies materially influenced by understandable nationalistic aspirations to become economically independent. Each of these countries is sub-divided into states or provinces, ${ }^{2}$ and these into other political sub-divisions corresponding generally to the counties, municipalities and

* B.A., r921, Whitman College, B.A. (Juris), 1923, B.C.L., I924, Oxford University. Member of the Idaho, Minnesota and New York Bars. Partner in charge of foreign law, Reid \& Priest, Attys., New York City. Author of Practical Aspects of Taxation in Latin America (1940) I8 TAX MAG. 539, 590, 621, 685, 689; Recent Trends in Regulation of Public Utilities in Latin Ametica (1941) Procerdings op Havana Conference of Inter-American Bar Assoctation, also published in Economi y Finanzas (Santiago de Chile) July, Aug., Sept., Oct., r94r.

In collaboration with Mr. Frank Mackenzie, New York City; Dr. Miguel Sussini, Buenos Aires; Mr. Reece Hatchitt, Rio de Janeiro; Mr. Thomas Perry, New York City; all of whom have contributed extensively to this article. We are also indebted to the consuls and other diplomatic representatives of many Latin American countries, who have been most helpful.

${ }^{2}$ For excellent summaries of commercial laws in many Latin American countries, we recommend an admirable series of pamphlets published by the Bureau of Foreiga and Domestic Commerce, U. S. Dep't of Commerce: Trading under the Laws of Argentina (1935); - of Brazil, (1938); — of Mcxico (1935); - of Peru (1930); - of Venezuela (1937). However, as will be noted, some of these pamphlets were published some years ago and, therefore, inquiry should be made to check subsequent changes in the laws. Also of interest are the following pamphlcts, all recently published: Prcparing Shipments to Veneztsela; —_ to Argentina; — to Nicaragua; _- to Pertt. For information bearing on the expense of maintaining an office abroad, see: Living and office-Operating Costs in Colombia; — in Puerto Rico; — in Trinidad. The Department of Commerce also issues "The Foreign Commerce Weekly" in which appear, from time to time, excellent digests of Latin American commercial laws.

${ }^{2}$ E.g., Argentina has 14 provinces, one federal district, and ro territories; Brazil, 20 states, onc federal district, and one territory; Chile, 25 provinces; Mexico, 28 states, one federal district, and two territories. 
other sub-divisions of an American state. As in the United States, each of these various sub-divisions usually has taxing power. Likewise, most of the innumerable varieties of taxes known to us are found in Latin America and the tax structure in some countries is, if possible, even more complicated. A study of the tax laws and procedure of the United States and each of its states and territories and their political sub-divisions would not be as arduous a task as one for Latin America.

It will thus be easily understood that, within the limited space alloted to this article, it is impossible to do more than indicate for what and where to look in approaching tax problems in our sister republics to the south. In choosing illustrations for the various points covered in this article, laws and precedents have been drawn from the countries with which the writer or one of his collaborators is most familiar. ${ }^{3}$ This by no means should be understood, however, as in any way minimizing the importance of the other countries or of their commerce. Finally it should be noted that, although European possessions and particularly the Dominion of Canada play an important role in hemispheric trade, they are not within the scope of this article.

\section{General Comments on Latin American Tax Laws and Their Administration ${ }^{4}$}

\section{Source of Authority to Tax}

Authority to tax in Latin American countries is generally derived from the national constitutions. As in the United States there is usually considerable overlapping of taxing authority between the national, state, and other taxing jurisdictions. For example, in Mexico some of the states impose their own sales taxes which are in addition to the Federal Sales Tax. ${ }^{5}$ However, there, as in most Latin American countries, the octroi ${ }^{6}$ is prohibited by constitutional provision but frequently (as is the case with us) it is evaded by obvious subterfuges. In Brazil the states may levy export taxes on goods produced therein up to $10 \%$ ad valorem. Brazil has a specific constitutional provision against double taxation; whenever the national government imposes a tax, similar taxes by subordinate jurisdictions are excluded. ${ }^{7}$

In some cases taxes are levied by the national or state governments and then distributed in accordance with law between other political sub-divisions. For example, in Brazil the states levy taxes on industries and professions, the proceeds of which are shared equally by the states and municipalities. In Uruguay the national government collects all real estate taxes but $75 \%$ must be turned over to the municipality in which the property is located.

\footnotetext{
${ }^{3}$ Thus citations to laws, etc., in the text and footnotes are merely illustrative and not intended as exhaustive. There is appended to the article a brief bibliography listing the principal primary and secondary sources for a number of Latin American countries.

'For a more complete discussion of this topic, see the author's Practical Aspects of Taxation in Latin America (1940) 18 TAx MAG. 539, 590, 621, 685, 689.

'Some states have sales taxes, while others tax invested capital engaged in active business operations.

- Imposition of taxes upon goods in transit from one subordinate political entity to another. In China such tax, imposed at provincial frontiers, was called "likin." It is really an internal customs levy.

7 Fed. Const. art. 24.
} 
Argentina offers an interesting, if not the sole, example in Latin America of a contractual arrangement (approved by law) between the national and provincial governments establishing the basis for sharing certain tax revenues, thus in effect limiting by treaty the constitutional taxing rights of the province. Chile represents the outstanding example of a country which has prohibited all taxation by municipalities, the taxes being levied by the national government and distributed according to law between the national, municipal, and other political sub-divisions.

\section{Multiplicity of Tax Laws}

In recent years there has been a marked tendency in Latin America to impose separate sales, income and other taxes, for specific purposes. This has resulted in great multiplicity and confusion of tax laws. Thus, instead of merely amending existing tax laws to produce a needed increase in revenues, a new tax of the same nature as one already existing is often imposed to cover a designated expenditure. For example, the "patriotic tax" of Ecuador, ${ }^{8}$ Cuba's Economic Emergency Law of $1931,{ }^{9}$ and the special taxes imposed in Chile for the benefit of survivors of the Chillán earthquake in January, $1939 .{ }^{10}$

As a result of this tendency to enact tax legislation piecemeal without codifying or revising it periodically, there is often an unbelievable multiplicity of similar taxes. A glance at the following bills for duties and other taxes on an imported cargo valued at 605 pesos gold and taxes on a moving picture theater with monthly gross revenues of 40,000 pesos, legal currency, in Chile ${ }^{11}$ will illustrate this point.

Actual Bill for Import and Other Duties Payadel on Account of Consignment or 605 Gold Pesos Value, Gross Weight 150 Kilos

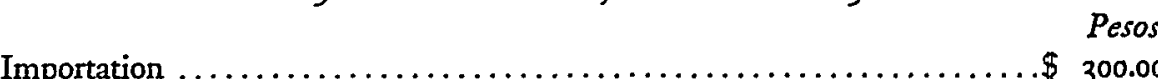

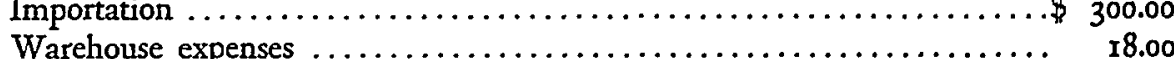

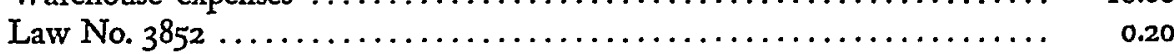

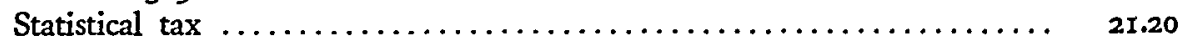

Law No. 485 I $\ldots \ldots \ldots \ldots \ldots \ldots \ldots \ldots \ldots \ldots \ldots \ldots \ldots \ldots \ldots \ldots \ldots \ldots \ldots \ldots, \quad 30.00$

Transportation $\ldots \ldots \ldots \ldots \ldots \ldots \ldots \ldots \ldots \ldots \ldots \ldots \ldots \ldots \ldots \ldots \ldots \ldots \ldots, \quad 5.00$

Pesos

Surcharge $-300 \%$ (because of depreciation of paper peso) ........... I,I23.20

Law No. $6915 \ldots \ldots \ldots \ldots \ldots \ldots \ldots \ldots \ldots \ldots \ldots \ldots \ldots \ldots \ldots \ldots \ldots \ldots \ldots, 391.80$

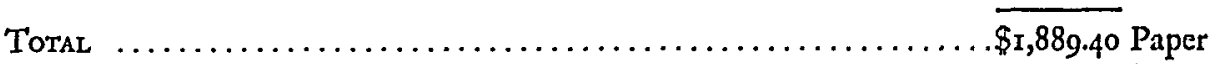

Pesos

${ }^{8}$ Introduced by decree No. 386 of 1936 , later doubled by decree No. 339 of Aug. 1937. There are some 49 documents listed in art. 3 on which patriotic stamps must be affixed.

${ }^{2}$ Ley de Emergencia Económica de Enero 28 de $193 x$. The purpose of this law is similar to the "patriotic tax" of Ecuador described in the preceding note.

${ }^{10}$ Ley No. 6334 de 1939 .

${ }^{11}$ The gold peso equals, approximately, $\mathrm{x} 2$ cents U. S. gold; the legal currency peso, approximately, 3 cents U. S. legal currency in free exchange. 
Taxes (Excluding Property Taxes) Payable by Moving Picture Theater with 40,000 Pesos per Month INCOMe

Monthly Fiscal and Municipal Taxes:

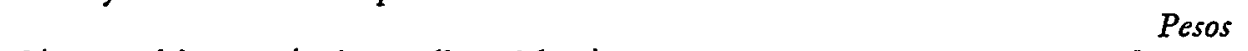

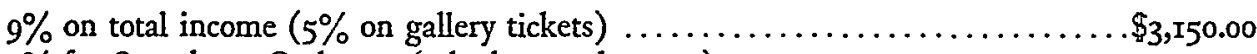

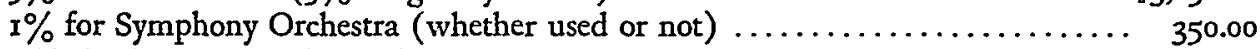

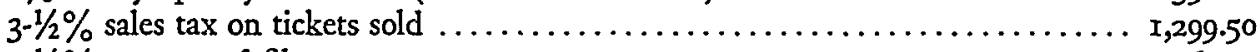

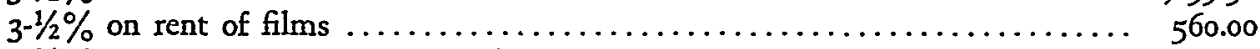

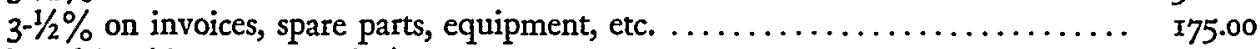

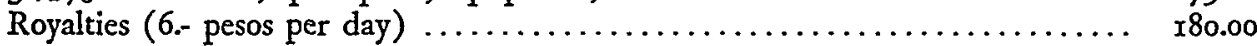

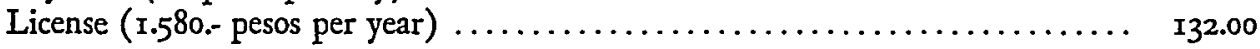

Municipal taxes:

For every one thousand programs $(2 .-$ pesos per day) $\ldots \ldots \ldots \ldots \ldots \ldots \ldots \ldots$ 60.00

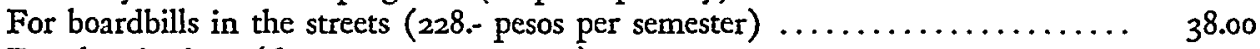

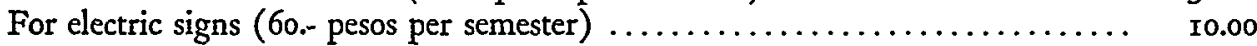

Fiscal taxes:

Social laws (employees contribution and gratification) $\ldots \ldots \ldots \ldots \ldots \ldots \ldots$ I,2 $2 \mathrm{I}_{4.9 \mathrm{I}}$

Income tax (upon estimated yearly net earnings of 18,000 pesos) $\ldots \ldots \ldots \ldots \ldots$ r. 554.00

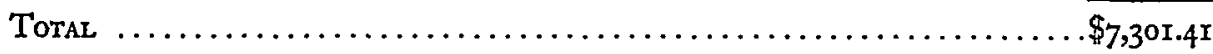

\section{Procedure for Contesting Tax Assessments ${ }^{12}$}

The methods of contesting claims for taxes naturally vary from country to country. However, speaking generally, the following are basic points to be considered where a tax liability is asserted which is believed to be unfounded:

a) A petition for review should first be presented to the tax or other administrative authorities having charge of the application of the particular tax in question. At the same time, the amount of the tax should ordinarily be paid or, in the few cases where the law permits, deposited with or guaranteed to the government or agency named by law for that purpose. Sometimes, it is possible to contest the tax without making payment, deposit or guarantee, but this is usually a very dangerous procedure since penalties and fines accumulate at a very rapid rate. While it is true that even if the contestant is unsuccessful in his appeal before the tax authorities or the courts, penalties and fines may sometimes be waived, there is no guarantee that this will be done even where the law authorizes condonation; and the larger the amount of the accrued fines and penalties, the more unlikely it is that they will be condoned. Ordinarily such fines and penalties equal the amount of the tax in anywhere from one to three years, and since usually at least this long will be consumed in litigation, it will readily be seen how much danger is involved in permitting their accumulation. (In Uruguay, failure to attach stamp taxes where required by law, authorizes the imposition of a penalty of ten times the amount of the tax.) The danger is even greater, where, as is the case in several countries, the citizen, (e.g., Chile and Guatemala) or public official (e.g., Brazil) who gives information leading

\footnotetext{
${ }^{12}$ For more detailed discussion of the various points mentioned under this heading, see Ford, supra note 4 .
} 
to the collection of back taxes shares in the fines and penalties and sometimes even in the taxes thus collected.

b) If the appeal to the administrative authorities is not successful, then the matter may be taken to the courts. Sometimes a direct appeal is permitted to the administrative or regular courts, whereas in other cases a new proceeding must be initiated. In cases where the law does not require previous payment and the taxpayer has elected not to pay the taxes, he may wait until action is brought by the government for their collection and defend in that proceeding. However, even in such cases the taxpayer may still be subject, at the discretion of the government, to an order for immediate payment, deposit or furnishing of security for the payment of the taxes or to penal interest and fines if he loses the lawsuit. It should also be noted that in some countries delinquent taxpayers are precluded, under certain circumstances, from performing many civil acts, such as the execution of public deeds, so that even though the taxpayer cannot be directly forced to pay the taxes until the litigation is completed, as a practical matter, if he is engaged in business in the country, he will find it necessary to make payment, deposit or guarantee thereof.

As examples of procedure for contesting tax claims, brief reference may be made to Brazil, Colombia and Argentina.

In Brazil, if federal taxes are involved, the taxpayer may appeal to one of the taxpayers' Councils. However, unless the amount claimed is paid or guaranteed by pledge of property or by a deposit of the amount in controversy the delinquent taxpayer cannot purchase stamps, dispatch merchandise through Customs or have other official dealings with any agency of the Government. The Federal Council (not yet functioning, however) may of its own initiative or at the request of a taxpayer order the suspension of a state tax covering the same field as a national tax.

In Colombia a taxpayer may appeal against an assessment to the Chief of the Tax Department. The appeal will receive scant consideration unless proof of payment is attached. From a decision of the Tax Department, the taxpayer may appeal to the Contentious-Administrative Courts. ${ }^{13}$ From the latter, appeal may be had to the Council of State. In Argentina a taxpayer may appeal to the Ministry of Finance, asking for refund of the alleged excess which he has been required to pay by the Tax Department. If the Ministry fails to reach a decision within nine months (four months in cases involving sales taxes) or if it renders a decision adverse to the taxpayer, the latter may initiate a claim against the government in the courts. In practice, the taxpayer should pay the amount in controversy and then proceed against the Tax Department. Where the latter fails to issue a ruling within four months, the taxpayer may have recourse to the Federal Courts. But if the department renders a decision within that period, the taxpayer must begin action within fifteen days or lose his rights.

c) Reliance upon statutes of limitation as a defense against collection of back

${ }^{13}$ I.e., tribunals having jurisdiction over disputes between the state and its citizens or other private persons. 
taxes is an uncertain protection. These statutes are frequently for very long periods, sometimes as long as thirty years or more. Frequently the statutes only start to run after returns have been filed by the taxpayer ${ }^{14}$ or the matter otherwise brought to the attention to the government, and even then only in case there was no intention to evade payment of the tax by withholding information or otherwise. It is thus readily seen that it is very easy for the courts to find an excuse for saying that prescription has never started, particularly since, as regards most kinds of taxes (other than income taxes), no return need be filed by the taxpayer or other act done which might be said to put the government upon notice. Even in the case of income taxes, acts frequently take place which give rise to tax claims on non-recurring income but which are likely to be overlooked in preparing the ordinary returns covering recurring earnings. ${ }^{15}$

d) Another source of danger is too much reliance on advance rulings from the tax authorities as protection against possible tax liability. ${ }^{16}$ This is a matter in connection with which great care must be exercised. In most countries there is no provision in the laws for such consultative rulings and, therefore, even though the authorities may be inclined to give an opinion, it usually has no legal validity. In some cases, such as in Chile and Brazil, there is provision for rulings, ${ }^{17}$ but as a rule they have no validity except in the particular cases to which they are directed and, in fact, are frequently disregarded in later cases. In other countries, such as in Mexico, rulings may be obtained but they are subject to reversal on application by the government to the Fiscal Court. ${ }^{18}$ In general it may be said that advance or advisory rulings are chiefly of value as good arguments for avoiding penal interest and fines, should tax liability later be asserted, but too much reliance should not be placed thereon, particularly where the amount of possible tax liability is large.

\section{Tax Exemption for New Industries}

Many Latin American countries contain somewhere in their laws provisions for tax exemption in a more or less limited form for new industries. Even where such provisions are not contained in existing laws, a new industry contemplating investment of a substantial sum of foreign capital can often obtain by special law a limited degree of tax exemption for a period of years. This is a matter which should be carefully studied where new industries are proposed to be established.

However, sometimes, as in Brazil, a very indefinite distinction is made between payments related to some actual or theoretical benefit or service rendered by the government (e.g., water, telegraph service) called "taxas," and true taxes, called "impostos." Therefore, an exemption from taxes (impostos) may be largely nullified by imposing charges which are really "impostos" but which are called "taxas."

${ }^{14}$ See decision of the Supreme Court of Chile in Sociedad Ferrocarril de Aguas Blancas, May I4, 1940, La JuRusprudencis as Dis (1940) 185. In Argentina, however, it appears that prescription runs from the date the taxes are due.

${ }^{15}$ For more detailed discussion of capital gains and losses under income tax law of Chile, see Ford, supra note 4 . ${ }^{18}$ See ibid.

${ }_{17}$ Brazil: Law 202 of March 2, 1936, art. I6; decree II37 of Oct. 7, 1936, art. 64; Chile: Law 5686 of 1935 , arts. 4,5 . 
In Guatemala, exemption may sometimes be obtained from import duties on the initial plant and machinery required by the industry. Occasionally raw materials also are allowed to be imported without paying duty. Any arrangement of this sort must be made with the Ministry of Finance which has jurisdiction over all tax matters. Mexico will sometimes lighten the tax burden on infant industries. For example, the Mexican Diario Oficial of April Ir, I94I, contains an authorization granting tax exemption for five years to certain specified industries. The exemptions cover the importation of machinery and various taxes. In Panama, no advantage is accorded the importer who brings in semi-manufactured articles with the purpose of assembling them in Panama.

In December 1938 the province of Buenos Aires enacted an interesting law granting not only to new industries, but also to existing industries, exemption from the taxes established between January I, I939, and December 3I, I948, and from any increase in then existing taxes, provided such industries could comply with certain prerequisites. Among these are the following:

I. To have no unpaid indebtedness to the Government;

2. To waive all judicial or administrative claims in connection with taxes;

3. To have $70 \%$ of their employees Argentinian;

4. To prefer Argentinian raw material where its quality and price are equal to that of imported material.

Title ${ }_{7}$, Section 4 of the Transitory Provisions of the new Cuban Constitution provides an interesting stimulant for those willing and able to pioneer new industries. ${ }^{19}$ Costa Rica encourages new capital through Law 36 of $x$ 941.

\section{Taxes Affecting the Traveling Representative}

The yeast which leavens all trade, hemispheric or world-wide, is that modern counterpart of the Phoenician merchant-the travelling salesman. Before the salesman (or other traveller) may enter another country he must, of course, get leave from the appropriate authorities of the nation concerned. Often this entails a money deposit, almost always a visa, and the fulfillment of certain other requirements before permission is issued. As these conditions frequently change, up-to-the-minute information should be obtained from the nearest Consulate of the country to which interest attaches. Also of use is the "Official Steamship \& Airways Guide International."

Sometimes a country will differentiate between naturalized and native-born United States citizens. ${ }^{20}$ Mexico will admit as commercial travellers only those visitors who intend to appoint, or consult with, distributors in Mexico. It is thought that there are already enough actual or potential salesmen of Mexican citizenship within the republic.

\footnotetext{
${ }^{19}$ Patentes de Introduccion Industrial. Opportunities for imported capital in Colombia are ably outlined in Bayon, Exchange Control in Colombia, Proinco (Bogotá, April 1941) 38.

${ }^{20}$ Colombia makes such a distinction between individuals born in the Latin American republics and subsequently naturalized in the United States and other naturalized United States citizens. The latter pay higher deposits at ports of entry and must also obtain special permits.
} 
Are the all-important sample cases of the salesman subject to customs duties? Here the procedure varies, as might be expected, from country to country. The general rule, however, makes all samples, whether sent directly or accompanying the traveller, dutiable. ${ }^{21}$ Exceptions are sometimes made where the samples have in themselves no commercial value, or have been rendered useless. Punching holes in the soles of shoes, mutilation of cotton fabrics by deep gashes, filing off a revolver barrel, removal of the metal foil attached to a stopper on a perfume bottle, would probably exempt such articles from duty.

Where samples are of commercial value a bond is usually required.22 The bond may be cancelled upon re-export of the goods within a certain period (usually from six months to one year). Duly licensed customhouse brokers can often furnish bond (as in Colombia) and sometimes a reputable merchant (as in Chile and Brazil). Mexico appears to make no provision for a bond; the full duty must be paid. In Guatemala the bond has to be made out in a sum equal to the equivalent duty. If a bond cannot be arranged, the salesman will have to pay the regular duty.

The salesman usually will have to pay duty on all advertising matter-circulars, cards, catalogues, pamphlets, prospectuses, posters, and calendars-brought in for complimentary distribution.

After complying with customs regulations and the passport control the salesman will, in many instances, have to register with the appropriate authorities. Most Latin American countries also require that a commercial salesman procure a license before doing business. Fortunately, the issuance of commercial licenses, in many of the countries, is regulated by treaty. Such a treaty is the "Convention Facilitating the Work of Travelling Salesmen" signed by the United States of Venezuela and the United States of America at Caracas, July 3, I919. ${ }^{23}$ All persons interested in hemispheric trade should study carefully this treaty, for it is the prototype of many others. $^{24}$ Briefly, Article I provides that commercial travellers of one of the high contracting parties may engage in business within the territorial limits of the other "on obtaining from the latter, upon payment of a single fee, a license which shall be valid throughout its entire territorial jurisdiction." Article IV allows the free entry of samples "without commercial value" and "samples marked, stamped, or defaced, in such manner that they cannot be put to other uses." Article VI declares: "All customs formalities shall be simplified as much as possible with a view to avoid delay in the despatch of samples." Obtaining a license in countries having this kind of treaty presents few difficulties.

In countries not covered by treaty, license fees may be prohibitive. In the Argen-

${ }^{21}$ However, Cuba allows free entry of felts and fabrics upon meeting certain requirements as to length and breadth. The Cuban tariff also exempts articles of a scientific or industrial character brought in for a limited time for demonstration purposes.

${ }^{22}$ E.g., in Argentina, Brazil, Chile, Costa Rica, Guatemala and Venezuela.

233 Mazloy's United States Treaties (r9io-I923, Sen. Doc. No. 348, 67th Cong., 4th Sess.) (1923).

24 Colombia (signed Bogotá, Aug. 4, 1922), Guatemala (signed Washington, Dec. 3, r918), Panama (signed Washington, Feb. 8, I919), Paraguay (signed Washington, Oct. 20, 1919), Peru (signed Lima, Jan. 19, 1923), Salvador (signed Washington, Jan. 28, I918), Uruguay (signed Washington, Aug. 27, 1918). 
tine, for example, a traveller who sells by sample must obtain a separate license from every province and territory through which he journeys. The grand total of such payments has been estimated at $M \$ N 6000$ (equal roughly to $\$ 1400$ ). Accordingly, the traveller may be forced to sell by catalog from headquarters only or work with one of the large importing houses of Buenos Aires, which themselves maintain agencies throughout the country.

Upon leaving some countries the salesman will have to pay a tax on his ticket which often may be avoided if he has purchased a circular or round-trip ticket before leaving the United States. In some instances he must also procure a clearance certificate $^{25}$ which will probably require payment of additional taxes, usually not substantial. Sometimes this will entail payment of income taxes even on compensation paid abroad, depending in some cases on the length of time he has stayed in the country. ${ }^{26}$ More curious still, some countries ${ }^{27}$ collect income taxes on the salesman's living expenses during his stay where he is on an expense account, on the theory that this is in effect additional compensation earned in the country. ${ }^{28}$

\section{Brief Comments on the More Important Taxes Afrecting Business}

The main source of tax revenue in Latin America is still the import duty. ${ }^{20}$ This is very different from the United States, France and England, which depend largely on income taxes and internal excise taxes.

The general sales tax ${ }^{30}$ is also popular in most countries of Latin America, because of simplicity in its application and its dependability as a source of income. Before the First World War it was confined to Mexico ${ }^{31}$ and the Philippine Islands and in those countries it no doubt had its origin in the most widely known of national sales taxes of the middle ages, the Spanish "alcabala." Since the First World War the various American governments, due in a large measure to the necessity of financing ever-increasing social legislation, national and hemispheric defense, and the everincreasing government subsidy of trade and industries, have resorted more and more to the sales and income taxes in an attempt to balance their budgets.

\section{Customs Duties}

Sooner or later, all merchandise which moves along the routes of hemispheric trade must pass the ubiquitous customs barrier. Generally, the provisions of the customs laws are highly technical and the wise importer will do well to entrust his

${ }^{25}$ E.g., in Chile, Costa Rica, Colombia, and, under some circumstances, Nicaragua.

${ }^{20}$ See section on "Income Taxes," infra p. 785 .

${ }^{27}$ E.g.; Chile, Mexico.

${ }^{28}$ Of general interest to travelling representatives are three short manuals, terse and precise, prepared by the U.S. Dep't of Commerce, Bureau of Foreign and Domestic Commerce. Each is called: "Commercial Travelers Guide to Latin America." Part I deals with the West Coast of South America; Part II with the East Coast; Part III with Mexico, Central America and the Caribbean countries.

${ }^{20}$ See TAx Systems of THE WORLd (8th ed., 1940). Recently, however, Argentina and Brazil have become exceptions to this rule.

${ }^{30}$ Also called (inter alia) turnover tax, gross receipts tax, producers tax, and even general stamp tax. Much confusion has resulted from lack of precision in nomenclature.

${ }^{31}$ A Mexican consumption tax, along Spanish lines, was introduced as early as 1856 . 
customs problems to an experienced broker on the spot. For illustration let us take a Brazilian firm in Río de Janeiro wanting to import goods from the United States.

First, the firm will have to arrange to procure a consular invoice from the Brazilian consulate nearest the United States port of loading, also a commercial invoice authentication. Fees are payable for both these documents. Upon arrival at Río de Janeiro a "despachante"32 should be hired to classify the goods. His is a most important task, for upon correct classification depends the importer's immunity from fine, and the customs authorities are entitled to one half of all fines levied. The fine for improper classification is twice the amount of the tax. The importer can readily see that the services of an expert "despachante" are indispensable.

Some six import duties and other taxes are payable on incoming articles: $(\mathrm{I})$ the principal duty per kilo or ad valorem, according to classification; (2) a surtax of $10 \%$; (3) $2 \%$ for social security; ${ }^{33}$ (4) a consumption tax; (5) a warehouse tax, and (6) other small taxes. ${ }^{34}$

In many instances (e.g., Chile, Colombia, Ecuador, Nicaragua, and Costa Rica), all importation of goods requires licenses from the exchange and importation control boards, and these may be difficult to get. Accurate classification of imported articles is also important under the customs tariffs of Colombia and Chile. Imports are there separated into various categories-categories too technical to be dealt with in the space available. Suffice it to say that certain categories enjoy priority with respect both to the granting of import licenses and reimbursement in foreign currency. In Mexico, prior customs classifications may be had from the Treasury Department, but only by a person established in the republic. This entails maintenance of a representative or agent in Mexico. Various technical rules surround the importation of merchandise by parcel post, in the form of baggage, or by air. If a United States exporter desires to arrange to be paid in produce, i.e., make a barter deal, he must bear in mind that licenses are sometimes also required to export products. ${ }^{35}$

\section{Income Taxes ${ }^{36}$}

The income tax is a subject so vast that it is impossible to do more than make a few illustrative comments in an article of this kind. Income tax laws in Latin America vary greatly from country to country. The first nation to adopt such a tax was Peru. It did so more than 85 years ago. The Argentine income tax dates from I932. Venezuela has today no income tax. Nicaragua and Uruguay tax not income but capital.

Generally, the basis for imposing the tax is nationality or residence, regardless of where the income is produced. However, Argentina only taxes income produced

\footnotetext{
${ }^{33}$ Literally, one who dispatches; in this case a customs broker.

${ }^{33}$ Certain commodities are exempted under commercial agreement with the United States from this tax. Among such articles are telephones, radios and ice boxes.

"For similar multiplicity of taxes on imports to Chile, see sample bill stpra p. 778 .

${ }^{a s}$ E.g., in Colombia for coffee, petroleum, gold, platinum, emeralds. Ecuador, too, requires export permits. In Venezuela, Law 30 of June, I $94 x$, provides that national producers of petroleum, coffee and cocoa must sell all foreign exchange to the Central Bank.

${ }^{30}$ For a somewhat more extensive discussion of income tax laws in Latin America, see Ford, supra note 4 .
} 
within the country. In some countries, income, patrimony and excess profits taxes are combined into a taxing triumvirate burdening income. Colombia furnishes an example of this latter type of income tax law. ${ }^{37}$

The income tax in Colombia dates from Law 8I of 193I. The excess profits tax is an additional levy upon "the excess of profits" obtained in any given year by the person subject to tax. The patrimonial tax is related to the net property of the taxpayer after deducting debts and charges. However, the patrimonial tax is considered an indivisible part of the other two; for it is collected by increasing the rate of tax on income produced by capital. Such has been the view of the government, supported by the Supreme Court. Transient foreigners are not liable to these taxes. But individuals who reside in the republic for more than six months in any given year, and do business there, must file a return. Persons, natural or juristic, not domiciled in Colombia, are taxed on income flowing from sources within Colombia. "Domicil" with respect to foreign companies is defined as having a management or business office in Colombia. Of particular importance to foreign businessmen is Decree 1892 of 1936 , which requires the tax on credits owned by non-resident creditors to be withheld at the source. Commercial paper evidencing debts incurred by reason of the importation of merchandise is, however, exempt.

The income tax law of Brazil is a different type of law, but also has interesting features bearing on hemispheric trade. Foreigners resident in Brazil for more than I2 months having a gross income of more than 12 contos (approximately U. S. $\$ 600.00)$ are, for income tax purposes, treated as Brazilian citizens, regardless of the source of their income. On the other hand, residents abroad with an income derived from sources within Brazil are considered taxpayers but are treated, according to article $\mathrm{x} 74$ of the Regulations, in a different manner. Pursuant to that article, a tax of $8 \%$ is payable on the income of a resident abroad, with no deductions being permitted. The amount of this tax is withheld at the source. Whether the income of a foreign corporation consists of the profits of a branch operating in Brazil or of dividends paid to it by a subsidiary Brazilian company, it is subject to the following taxes:

I) a tax of $6 \%$ on the operating results of the branch or subsidiary declared and paid by said branch or subsidiary;

2) a tax of $8 \%$ on profits credited or remitted by a branch to its home office abroad or on dividends credited or remitted thereto.

A further tax of $5 \%$ is levied on all remittances abroad although this tax is not strictly speaking an income tax. According to the letter of article 174 , only an additional $4 \%$ tax is payable in the case of funds which have already been taxed at the rate of $6 \%$ in the hands of the corporation or firm remitting the same. In actual practice, however, the $8 \%$ rate is assessed in addition to the normal corporation tax of $6 \%$. This result has been reached through interpretation by the taxing authorities of the income tax law and article 17 , paragraph 2 of decree-law 1168 of March 22,

\footnotetext{
${ }^{37}$ See laws $8 \mathrm{x}$ of $193 \mathrm{x}, 78$ of $x 935,63$ of 1936 and 48 of $x 937$.
} 
I939. One interpretation is that the last mentioned law has, in effect, repealed the last part of article 174 of the Regulations, although as yet the Brazilian Supreme Court has not passed on the matter. Capital gains and losses and other forms of non-recurring income and deductions therefrom always present difficult problems full of danger to the businessman, because they are so readily overlooked and may result in large tax liability. ${ }^{38}$

The travelling salesman is sometimes exempt from income tax. For example, the traveller who passes through territory of the Republic of Panama and who restricts himself solely to taking orders, need not pay any tax whatsoever on his salary or commission. Nor is the company on whose account the agent makes sales burdened by any tax.

In Guatemala a representative who acts as the selling agent of a New York company which credits his commissions to a New York bank account need pay no income tax thereon. The same exemption applies to a partner in Guatemala of a New York firm; for the profits paid him in New York are not subject to tax. However, all profits received in Guatemala are taxed.

A foreigner in transit in Brazil for more than three months, who receives monies in excess of 10,000 milreis (roughly U. S. $\$ 500$ ), must pay an income tax. He must file a return before leaving the country. In Chile, a foreigner with a commercial visa must pay on his income earned and paid in Chile, no matter how short his stay; if it exceeds six months he is considered a resident and must pay on the same basis as a citizen of Chile.

\section{The Sales Tax}

The sales tax (like the income tax) has so many variations and forms that differ from country to country, that we can do little more than indicate salient features in a few countries.

In the Argentine a national sales tax was established by congressional law of December 28, I934. The law taxes sales of merchandise in the internal market as well as goods destined for export. Each item has only to pay once no matter how frequent the subsequent turnover. The tax adheres to the net price, by which is meant the price obtained after discounts and rebates. Many commodities of prime necessity (food, fuel, etc.) sold within the Argentine are exempt from the tax, as well as books, magazines and sales by cooperative societies. The rate of the tax is $1.25 \%$ on internal sales, three per thousand on exports.

Excise taxes are levied in Argentina upon a variety of commodities, among which are tobacco, matches, beer, wine, articles of adornment, and medicines. Important is a tax on insurance policies taken out with foreign companies having neither representation nor agencies within the republic. ${ }^{39}$ Seven per cent is levied upon premiums

\footnotetext{
${ }^{38}$ See Ford, supra note 4 .

${ }^{30}$ Panama and Cuba also tax policies taken out with insurance companies which maintain no legal representatives there.
} 
which are paid on general policies; $2 \%$ on life policies; and a tax, progressive, but not very high, on the total amount of insurance carried.

Brazil has a consumption tax (Imposto de Consumo).40 It covers a list of more than 200 articles among which are cigarettes, furniture, paper, perfume and cement. Ordinarily, the article sold must carry tax stamps in the correct amount. The gluing on of stamps is a cumbersome process. First, they are purchased in large sheets from the government. They must then be separated and glued (the stamps are not gummed). For example, every flashlight bulb must have a separate stamp; and the stamps must stick on. If they do not, heavy fines are imposed. One of the major problems facing vendors of bottled drinks is to find a method of keeping stamps on the individual bottle-particularly difficult in view of the fact that the bottles are usually kept in containers filled with ice water. Those few articles which do not require stamps must be accompanied by a "guia," or receipt, when sold or transported.

Besides the tax charged on the article the manufacturer or importer must also pay a "Patente de Registro," or a registration fee. This is designed to cover the cost of the collection of the consumption tax itself. For wholesale establishments the registration fee is based upon the variety of the goods sold and the capital invested in the enterprise. In computing the tax for factories the number of horse-power employed is also considered.

The Brazilian states also tax sales and consignments. Federal Decree Law No. 915 of December I, 1938, establishes the rules pursuant to which the states are permitted to levy this tax. This latter declares that the tax is incurred at the place where the sale or consignment is effected, i.e., where the establishment of the vendor or consignor is situated. If the manufacturer himself sells goods the sale is deemed to have been made at the place where the goods were produced. Transactions between branches of the same firm are exempt. Where the branch is in a different state from the main office the tax is paid at the place of origin. The state of destination can only tax when the subsequent sales price exceeds the price paid in the original transaction. In sales on credit, the tax is payable by affixing stamps to the sales receipt (factura), issued at the time the sale is made. In cash sales the tax is paid by pasting stamps in a book kept for such purpose.

Many problems arise under the sales tax which bear directly on hemispheric trade. A New York exporter wishing to enter, for example, the Brazilian market may, of course, advertise his product and then ship directly to the Brazilian consumer. Or he may wish to have a sales outlet in Río de Janeiro. The question arises whether the sale to the ultimate purchaser takes place in New York or in Brazil, in which case it would be subject to tax there. It appears to be fairly well settled that a mere intermediary in Brazil does not bring the sale to that country. But the difficulty lies in defining "intermediary." In one case, entries made in the books of the ultimate

${ }^{10}$ See decree-law No. 739 of Sept. 24, I938, with Regulation; also decree-laws Nos. 828 of Nov. I, 1938, 887 of Nov. 24, 1938, 934 of Dec. 8, 1938, 1104 of June 6, 1939, 1867 of Dec. 13, 1939, 2580 of Sept. 13, 1940. 
purchaser in Río de Janeiro were examined and found sufficient to establish that the sale took place in Brazil. Accordingly, the exporter must take care before setting a price on his products or he may receive a request from his importer to pay the sales tax- $-25 \%$ of the value of the sale if made in Río de Janeiro.

In Mexico the branch or agency of a foreign exporter must pay the tax on sales made by such agency, whether the goods are supplied from stock or shipped to the customer pursuant to order from such branch or agency. When there is no true agent, and invoice and shipping documents are sent directly to consumer, no tax need be paid. But if the documents are issued in favor of an agent, the latter must pay the tax. Travelling salesmen, making sales and themselves delivering, must have their invoice books authorized in places where they trade.

\section{Taxes on Remitrance of Funds}

In addition to the problem in many countries of obtaining permits for the remittance abroad of the proceeds from sales, especially as to that portion thereof which may represent profits, many countries impose a substantial tax on the export of funds. The availability of foreign exchange and the cost of procuring it is one of the major problems which should be carefully investigated in deciding whether a business venture is likely to be worth while.

\section{Advantages of Different Methods of Doing Business ${ }^{4 x}$}

Speaking generally and from a strictly tax point of view the advantages of doing business through locally incorporated or organized subsidiaries or agencies are becoming more and more important. Not only is there a tendency to impose greater tax burdens on foreign concerns as compared with locally organized ones but much more important is the fact that the income tax rates are much higher in the United States than in most Latin American countries. This means that although an American corporation doing business in Latin America will be able to take credit in its United States income return for income taxes paid abroad, that credit will in most cases be much less than the United States tax. On the other hand; a locally incorporated subsidiary or agent need only pay local taxes on the interest or dividend received, ordinarily with credit for such taxes thereon paid abroad. So important is that that some concerns are now going to great expense to convert subsidiaries incorporated in the United States to local companies. A further advantage thus gained is that there are avoided the serious problems of allocation of capital and expenses between different countries and resulting double taxation which often accompanies the qualification of the home company to do business abroad.

\section{ConcLuston}

If, after reading the foregoing discussion, you feel somewhat discouraged over the prospects of engaging in hemispheric trade, we would remind you that much of the

"1 For a general treatment of this problem, see Butte, Methods of Doing Business in Latin America, supra p. 752. 
apparent confusion and intricacy is the result of attempting to deal with the tax laws of twenty independent countries. Whenever one approaches a new subject, especially a subject as complicated as taxation always is, even in the simplest cases, one usually feels discouraged at first. A Latin American merchant proposing to engage in business in the United States would undoubtedly find that his attempt to understand and comply with the massive array of federal, state and municipal tax laws of the United States, would be a much greater task than for a North American merchant to attempt to do the same with respect to any one country in South America. This proves the statement just made, namely, that the difficulty for the North American merchant is not so much the complexity of the laws of any one country, as the fact that in most cases, if the business is to be worth while, it must be extended to a number of countries, each with its own different system of taxation.

As a final word of caution, let us repeat what we said at the beginning, namely, that this article is only intended to indicate what to look for and where to find it; and before anyone not experienced in hemispheric trade should consider embarking in a business venture in Latin America, he should consult with the persons most qualified to advise him in detail with respect to the tax and other problems likely to be encountered in the countries where he contemplates doing business.

\section{BibLIOGRAPHY*}

\section{Argentina}

Boletin Ofictal (Buenos Aires) (see, also, provincial gazettes)

R. Bielsa, Derecho Administrativo (Buenos Aires, i939)

J. A. Gonzalez Calderon, Derecho Constituctonal Argentino (Buenos Aires, I923)

Ricardo M. Duwavanan, Guia del Impuesto a las Ventas (Buenos Aires, r941)

R. M. Duwavran y J. E. De La Muela, Guia del Impuesto a los Reditos (Buenos Aires, 4th ed., 194I)

J. A. and E. de Marvat, Laws of Argentina (Buenos Aires, 1933)

Marval, Huntington and Marval, The Argentine Income Tax Laws and RegulatTons Thereunder

Mayer, Lobos y Clusellas, Impuesto a los Reditos (Recopilacion de Leyes, Decretos, Resoluciones y Jurisprudencia) (Buenos Aires, 1939)

Ropue V. Pandolfo, Ley de Papel Sellado (Texto Ordenado y su Decreto Reglamentario, Manual y Jurisprudencia Administrativa) (Buenos Aires, r933)

Raimundo M. Salvat, Tratado de Derecho Crvil Argentino (Buenos Aires, r928)

Egidio C. Trevisan, Los Impuestos Internos en la Republica Argentina (Buenos Aires, I934)

II. Brazil

Diario Ofictal (both federal and state)

O Observador Economico e Financeiro (Rio de Janeiro) (economic and financial monthly, with contributions on tax matters)

Revista Fiscal e de Legistacao de Fazenda (bi-weekly, Rio de Janeiro)

A Revista Forense (legal monthly) (Rio de Janeiro)

* The list is far from exhaustive. Early works of historical import are entirely omitted. In any one country, the constitution and codes, jurisprudence and legislation, must all be examined. 
Mozart da Gama, Como se deve pagar o Imposto de Renda (Freitas Bastos, Rio dé Janeiro, I94I)

Mozart da Gama, Direito Trubutario e Justica Fiscal (Freitas Bastos, Rio de Janeiro, 194I)

Pontes de Mrranda, Comentarios a Constituicao Federal de io de Novembro de I937 (Pongetti Bros., Rio de Janeiro, 1938)

De Placido e Silva, Nocoes de Financas e Direito Fiscal (Editora Guaira Ltda., Rio de Janeiro)

Tito Rezende, Manual Pratico do Imposto de Renda (Sfreddo \& Gravina Ltda., Rio de Janeiro, $2 \mathrm{~d}$ ed.)

III. Chile

Diario Oficial (Santiago de Chile)

Ley No. 6457 sobre Impuesto a la Renta (Leyes y Decretos que la compleMENTAN) (Santiago de Chile, r940)

Seguros E IMPuestos (periodical containing tax rulings, court decisions, etc.)

\section{Colombia}

Diario Oficial (Bogota)

Impuestos Nacionales, al Cuidado de la Jefatura de Rentas e Impuestos NaCIONALES (Imprenta Nacional, Bogota, I932)

Proyecto de Ley sobre Reforma Tributaria presentado al Congreso de I935 (Imprenta Nacional, Bogota, I935)

Manuel A. Alvarado, Cartilla de Hacienda (privately published, i934)

Manuel A. Alvarado y James W. Rausbeck, JR., Colombia-su Impuesto sobre la Renta, Patrimonio y Exceso de Utilitades (privately published, 1938)

Miguel Moreno Jamamillo, Ley de Leyes (Medellin, I932)

James Wallace Raisbeck, JR., Business Law of Colombia (Jarrett Printing Co., Charleston, W. Va., r940) (introduction by Dr. Jorge Gartner, Minister of Government)

\section{Costa Rica}

LA Gaceta (San Jose)

Soley Guell, Elementos de Ciencia Hacendaria (San Jose, 1929)

VI. Cuba

Gaceta Oficial (La Habana)

Carlos Sanchez Beato, Compilacion de los Impuestos del Estado (La Habana, undated)

Jose Maria Perez Cubillas, Legislacion Fiscal Cubana (Evolucion Historica, Legislacion Positiva, Jurisprudencia y Comentarios) (La Habana, r936)

Roswell Magill and Carl Shoup, The Cuban Fiscal System (New York, I939) (In Spanish and English)

Jesus Montero, Impuesto sobre Utiltdades (La Habana, I936)

Arsento Roa y Domingo Santodomingo, Ensayo de Hacienda Publica (La Habana, I927)

E. R. A. Seligman y Carl S. Shoup, Informe sobre el Sistema Tributario de Cuba (La Habana, I932)

\section{Ecuador}

Registro Oficial (Quito) 


\section{Guatemala}

Diario de Centro America (Guatemala)

IX. Mexico

Diarro Ofictal (Mexico, D. F.) (see also official state publications)

X. Panama

Gazeta Oficial (Panama)

Federal Income-Patrimonio Tax Law (Law No. 62 of r938)

Fondo Obrero y Del Agricultor (Capital Neto) (Panama, r939)

Leyes Nactonales Relacionadas con el Comercio (Camara de Comercio, Industria y Agricultura de Panama, I94r)

Raimundo Ortega Vieto, Hacia la Reforma Tributaria en Panama (Panama, 1939)

XI. Venezuela

GazeTa Oficial (Caracas)

Compilacion de Leyes y Decretos (Ministerio de Hacienda, Caracas, Imprenta Nacional, I94 I) 